\title{
PENGARUH KEPEMILIKAN MANAJERIAL, KEPEMILIKAN INSTITUSIONAL, KEPEMILIKAN PUBLIK, DEWAN KOMISARIS, DAN KOMITE AUDIT TERHADAP MANAJEMEN LABA (Studi Empiris Pada Perusahaan Indeks High Dividend 20 Di Bursa Efek Indonesia Tahun 2018-2019)
}

\author{
Amalia Utami $^{1}$, Siti Nur Azizah ${ }^{2 *}$, Azmi Fitriati ${ }^{3}$, Bima Cinintya Pratama ${ }^{4}$ \\ Fakultas Ekonomi dan Bisnis, Universitas Muhammadiyah Purwokerto \\ sitinurazizah@ump.ac.id*
}

\begin{abstract}
ABSTRAK
Tujuan penelitian ini untuk mengetahui pengaruh kepemilikan manajerial, kepemilikan institusional, kepemilikan publik, dewan komisaris, dan komite audit. Pemilihan sampel dalam penelitian ini dilakukan dengan purposive sampling. Berdasarkan kriteria didapatkan 56 sampel amatan. Teknik analisis data yang digunakan dalam penelitian ini yaitu statistik deskriptif, uji asumsi klasik, dan analisis regresi berganda. Hasil analisis menunjukan bahwa secara parsial kepemilikan manajerial tidak berpengaruh terhadap manajemen laba, kemudian kepemilikan institusional dan kepemilikan publik secara parsial berpengaruh negatif terhadap manajemen laba. Sedangkan dewan komisaris berpengaruh positif terhadap manajemen laba. Sementara itu komite audit tidak berpengaruh terhadap manajemen laba.
\end{abstract}

Kata kunci: kepemilikan manajerial, kepemilikan institusional, kepemilikan publik, dewan komisaris, komite audit, manajemen laba.

\begin{abstract}
The purpose of this study was to determine the effect of managerial ownership, institutional ownership, public ownership, the board of commissioners, and the audit committee on earnings management. The sample selection in this study was carried out by purposive sampling method. Based on the stated criteria, obtained 56 samples of observation data. The data analysis techniques used in this study were descriptive statistics, classical assumption tests, and multiple regression analysis. The results of the analysis show that partially managerial ownership has no effect on earnings management, institutional ownership and public ownership partially have negative effects on earnings management. Meanwhile, the board of commissioners has a positive effect on earnings management. furthermore, the audit committee has no effect on earnings management.
\end{abstract}

Keywords: Managerial Ownership, Institutional Ownership, Public Ownership, Board of Commissioners, Audit Committee, Earnings Management.

\section{PENDAHULUAN}

Salah satu tingkat keberhasilan perusahaan dapat dilihat dari laporan keuangan yang dimiliki perusahaan tersebut (Susanto \& Pradipta, 2016). Agar stakeholder tidak keliru dalam mengambil keputusan maka terdapat beberapa hal yang perlu diperhatikan, salah satunya adalah informasi terkait perkembangan sebuah perusahaan selama beberapa waktu melalui laporan keuangan perusahaan tersebut. Stakeholder berfokus pada perkembangan laba dalam perusahaan tersebut. Oleh karena itu perusahaan akan menampilkan laporan keuangan sebaikbaiknya sehingga stakeholder tertarik untuk menjalin kerjasama dengan 
perusahaan tersebut, cara yang sering digunakan adalah dengan manajemen laba (Susanto \& Pradipta, 2016). Manajemen laba dibuat untuk menarik stakeholder agar menaruh kepercayaan kepada perusahaan melalui laporan keuangan yang disajikan, hal tersebut yang terkadang menjadikan perusahaan mengupayakan agar manajemen laba perusahaan tersebut terlihat baik oleh stakeholder dan merupakan pemicu adanya manipulasi laba perusahaan (Pricilia \& Susanto, 2017).

\section{TINJAUAN PUSTAKA DAN PENGEMBANGAN HIPOTESIS}

Teori Akuntansi Positif menurut Watts dan Zimmerman (1986) yang menjelaskan tentang kebijakan akuntansi dan praktiknya dalam perusahaan serta memprediksi kebijakan apa yang akan dipilih manajer dalam kondisi-kondisi tertentu dimasa yang akan datang. Teori ini memprediksi adanya tiga hipotesis yang mendorong manajemen untuk melakukan manajemen laba. Ketiga hipotesis tersebut yaitu: hubungan keagenan antara manajer dengan pemilik (bonus plan hypothesis), hubungan keagenan antara manajer dengan kreditur (debt to equity hypothesis), Hubungan keagenan antara manajer dan pemerintah (political cost hypothesis).

Teori agensi adalah sebuah teori yang menjadi dasar hubungan antara pemilik (principal) dengan pengelola (agent). Menurut Jensen dan Meckling (1976) hubungan antara pemilik (principal) dengan pengelola (agent) terjadi karena adanya sebuah kontrak dimana pengelola (agent) diminta untuk melakukan jasa atas nama pemilik (principal) sekaligus memberikan beberapa wewenang untuk mengambil keputusan kepada pemiik (principal). Principal menyediakan fasilitas dan dana untuk mengelola perusahaan, di lain pihak agent mempunyai kewajiban untuk mengelola perusahaan sesuai dengan yang diamanahkan oleh pemegang saham sekaligus memberikan laporan periodik pada principal tentang usaha yang dijalankannya. Hubungan tersebut menimbulkan terjadinya konfik yang dinamakan konflik agensi (Jensen dan Meckling, 1976).

Sulistyanto (2018) menyatakan manajemen laba dapat dikatakan sebagai upaya manajerial untuk mengintervensi informasi dalam laporan keuangan dengan cara memanfaatkan kebebasan memilih dan menggunakan metode akuntansi dan menentukan nilai estimasi akuntansi. Upaya mempengaruhi laporan keuangan tersebut dapat dilakukan dengan berbagai macam cara sesuai dengan kepentingan manajer, selama yang dilakukan manajer masih dalam ruang lingkup prinsip akuntansi berterima umum maka akan tetap diakui dan diperbolehkan. Manajemen laba adalah suatu tindakan memaksimumkan atau meminimumkan laba untuk tujuan tertentu (Copeland, 1968). Manajemen laba adalah alat sah manajer untuk melakukan tanggung jawab untuk mendapatkan keuntungan atau return perusahaan (Fischer dan Rosenzweigh 1995).

Herawaty (2007) berpendapat bahwa kepemilikan saham perusahaan yang dimiliki oleh manajemen secara pribadi termasuk didalamnya dewan direksi, dewan komisaris dan komite audit dinamakan kepemilikan manajerial.

Saham perusahaan tidak hanya dimiliki oleh pihak manajer perusahaan, namun juga dimiliki oleh institusi dan saham perusahaan yang dimiliki oleh intitusi termasuk didalamnya adalah bank, perusahaan asuransi, perusahaan dana pensiun, perusahaan investasi dan yayasan adalah kepemilikan institusional (Saptantinah, 2005). 
Menurut Wijayanti (2009) masyarakat umum yang tidak memiliki hubungan istimewa dengan perusahaan dapat memiliki saham perusahaan, proporsi atau jumlah kepemilikan saham tersebut dinamakan kepemilikan publik.

Definisi dewan komisaris menurut Komite Nasional Kebijakan Governance (KNKG 2006) adalah bagian dari organ perusahaan yang bertugas dan bertanggungjawab secara kolektif untuk melakukan pengawasan dan memberikan nasihat kepada direksi serta memastikan bahwa perusahaan melaksanakan Good Corporate Governance, namun dewan komisaris tidak diperbolehkan untuk turut serta dalam mengambil keputusan operasional.

Keputusan Menteri Badan Usaha Milik Negara (BUMN) Nomor: Kep103/MBU/2002, yang menyatakan bahwa komite audit adalah suatu badan yang berada dibawah komisaris yang sekurang-kurangnya minimal satu orang anggota komisaris, dan dua orang ahli yang bukan merupakan pegawai BUMN yang bersangkutan yang bersifat mandiri baik dalam pelaksanaan tugasnya maupun pelaporannya dan bertanggungjawab langsung kepada komisaris atau dewan pengawas.

\section{METODE}

Sampel dipilih berdasarkan populasi perusahaan yang termasuk indeks Hidiv20 di Bursa Efek Indonesia tahun 2018-2019. Teknik pemilihan sampel dalam penelitian ini adalah teknik purposive sampling dengan kriteria pemilihan sampel sebagai berikut:

1. Perusahaan yang pernah masuk indeks Hidiv20 di Bursa Efek Indonesia pada periode tahun 2018-2019 secara berturut-turut.

2. Perusahaan menyajikan laporan keuangan secara konsisten pada periode pengamatan, yaitu periode tahun 2018-2019.

3. Laporan keuangan yang disajikan memiliki kelengkapan data yang digunakan untuk penelitian.

\section{HASIL PENGUJIAN HIPOTESIS}

a. Analisis Statistik Deskriptif

Hasil Analisis Deskriptif

\begin{tabular}{llllll}
\hline & N & Minimum & Maximum & Mean & Std. Deviation \\
\hline Kepemilikan Manajerial (KM) & 56 & 0,000001 & 0,1243 & 0,009691 & 0,0320645 \\
Kepemilikan Institusional (KI) & 56 & 0,17 & 0,85 & 0,5554 & 0,14471 \\
Kepemilikan Publik (KP) & 56 & 0,01 & 0,50 & 0,3280 & 0,15000 \\
Dewan Komisaris (DK) & 56 & 2,00 & 6,00 & 3,6071 & 1,21623 \\
Komite Audit (KA) & 56 & 2,00 & 9,00 & 3,8571 & 1,31327 \\
Manajemen Laba (ML) & 56 & $-0,19$ & 1,04 & 0,0480 & 0,17082 \\
Valid N (listwise) & 56 & & & & \\
\hline
\end{tabular}


RATIO: Reviu Akuntansi Kontemporer Indonesia 2021, 2 (2)

\section{b. Uji Normalitas}

Hasil Uji Normalitas Kolmogorov-Smirnov

\begin{tabular}{lll}
\hline & Standardized Residual & Keterangan \\
\hline $\mathrm{N}$ & $\mathbf{5 6}$ & \\
Kolmogorov-Smirnov Z & $\mathbf{0 , 9 2 2}$ & \\
Asymp. Sig. (2-tailed) & $\mathbf{0 , 3 6 4}$ & Lolos Uji Normalitas \\
\hline
\end{tabular}

Hasil uji normalitas terhadap 56 sampel menunjukkan hasil bahwa asumsi normalitas pada model regresi terpenuhi. Hal ini ditunjukkan dengan nilai signifikansi lebih besar dari 0,05 atau nilai signifikansi sebesar 0,364>0,05. Hal tersebut menunjukkan bahwa data berdisrbusi normal.

\section{c. Uji Multikolinearitas}

\begin{tabular}{llll} 
& \multicolumn{3}{l}{ Hasil Uji Multikolinearitas } \\
\hline Variabel & Tolerance & VIF & Keterangan \\
\hline Kepemilikan Manajerial (KM) & 0,807 & 1,239 & Bebas Multikolinearitas \\
Kepemilikan Institusional (KI) & 0,947 & 1,056 & Bebas Multikolinearitas \\
Kepemilikan Publik (KP) & 0,792 & 1,263 & Bebas Multikolinearitas \\
Dewan Komisaris (DK) & 0,902 & 1,109 & Bebas Multikolinearitas \\
Komite Audit (KA) & 0,860 & 1,163 & Bebas Multikolinearitas \\
\hline
\end{tabular}

Hasil pengujian multikolinearitas pada pengujian terhadap 56 sampel menunjukkan bahwa tidak terjadi multikolinearitas pada data penelitian. Hal ini ditunjukkan dengan nilai tolerance yang dihasilkan $<1$ dan nilai VIF $<10$, sehingga dapat disimpulkan bahwa variabel bebas dalam penelitian ini tidak saling berkorelasi.

\section{d. Uji Heteroskedastisitas}

Hasil Uji Heteroskedastisitas menggunakan Uji Park

\begin{tabular}{lll}
\hline Variabel & Sig. & Keterangan \\
\hline Kepemilikan Manajerial (KM) & 0,368 & Bebas Heteroskedastisitas \\
Kepemilikan Institusional (KI) & 0,493 & Bebas Heteroskedastisitas \\
Kepemilikan Publik (KP) & 0,330 & Bebas Heteroskedastisitas \\
Dewan Komisaris (DK) & 0,379 & Bebas Heteroskedastisitas \\
Komite Audit (KA) & 0,899 & Bebas Heteroskedastisitas \\
\hline
\end{tabular}

Hasil pengujian heteroskedastisitas dengan menggunakan uji park pada 56 data sampel menyatakan hasil uji heteroskedastisitas dengan tingkat kepercayaan 5\%, memperoleh nilai signifikansi > 0,05. Maka dapat disimpulkan bahwa data tersebut terbebas dari gejala heteroskedastisitas. 


\section{e. Uji Autokorelasi}

\begin{tabular}{lllllll}
\multicolumn{7}{c}{ Hasil Uji Autokorelasi } \\
\hline Model & Durbin-Watson & $\mathbf{d L}$ & $\mathbf{d U}$ & 4-dL & 4-dU & Hasil \\
\hline 1 & 2,102 & 1,3815 & 1,7678 & 2,6815 & 2,322 & $\begin{array}{l}\text { Bebas } \\
\text { Autokorelasi }\end{array}$ \\
& & & & & &
\end{tabular}

Hasil pengujian Autokorelasi menggunakan lima variabel independen. Nilai Durbin-Watson yang dihasilkan yaitu sebesar 2,102. Sedangkan nilai $\mathrm{dL}=1,3815$ dan nilai $\mathrm{dU}=1,7678$, sedangkan 4 -dU $=2,322$. Nilai Durbin Watson (DW) lebih besar dari dU dan lebih kecil dari 4-dU atau $1,7678<2,102<2,322$ maka keputusannya adalah tidak ada gejala autokorelasi dalam data penelitian.

\section{f. Analisis Regresi Linier Berganda}

Hasil Analisis Regresi Linier Berganda

\begin{tabular}{llllll}
\hline & \multicolumn{2}{l}{$\begin{array}{l}\text { Unstandardized } \\
\text { Coefficients }\end{array}$} & \multicolumn{2}{l}{$\begin{array}{l}\text { Standardized } \\
\text { Coefficients }\end{array}$} \\
& B & Std. Error & Beta & T & Sig. \\
\hline Konstanta & 0,363 & 0,094 & & 3,869 & 0,000 \\
Kepemilikan Manajerial (X1) & $-0,262$ & 0,563 & $-0,049$ & $-0,465$ & 0,644 \\
Kepemilikan Insitusional (X2) & $-0,497$ & 0,115 & $-0,421$ & $-4,316$ & 0,000 \\
Kepemilikan Publik (X3) & $-0,666$ & 0,121 & $-0,584$ & $-5,480$ & 0,000 \\
Dewan Komisaris (X4) & 0,045 & 0,014 & 0,324 & 3,238 & 0,002 \\
Komite Audit (X5) & 0,005 & 0,013 & 0,035 & 0,346 & 0,731 \\
\hline
\end{tabular}

Persamaan regresi linear berganda yang dapat dirumuskan pada penelitian ini adalah sebagai berikut:

$\mathrm{L}=0,363-0,262 \mathrm{KM}-0,497 \mathrm{KI}-0,666 \mathrm{KP}+0,045 \mathrm{DK}+0,005 \mathrm{KA}+\mathrm{e}$

\section{g. Uji Kelayakan Model (Uji Statistik F)}

Hasil Uji Statistik F

\begin{tabular}{|c|c|c|c|c|c|c|}
\hline \multicolumn{2}{|c|}{ Model } & \multirow{2}{*}{$\frac{\text { Sum of Squares }}{0,882}$} & \multirow{2}{*}{$\frac{\mathrm{Df}}{5}$} & \multirow{2}{*}{$\frac{\text { Mean Square }}{0,176}$} & \multirow{2}{*}{$\frac{F}{12,205}$} & \multirow{2}{*}{$\frac{\text { Sig. }}{0,000^{\circ}}$} \\
\hline 1 & Regression & & & & & \\
\hline & Residual & 0,723 & 50 & 0,014 & & \\
\hline & Total & 1,605 & 55 & & & \\
\hline
\end{tabular}

Diketahui bahwa nilai signifikansi yang diperoleh adalah sebesar 0,000 yang berarti nilai signifikansi tersebut lebih kecil dari nilai signifikansi yang digunakan yaitu sebesar 0,05 atau $0,000<0,05$, maka dapat disimpulkan bahwa model regresi dalam penelitian ini dapat dikatakan layak. 


\section{h. Uji Koefisien Determinasi $\mathbf{R}^{2}$}

Hasil Uji Koefisien Determinasi $\mathbf{R}^{2}$

\begin{tabular}{lllll}
\hline Model & $\mathrm{R}$ & R Square & $\begin{array}{l}\text { Adjusted } \\
\text { Square }\end{array}$ & $\begin{array}{c}\text { R Std. Error of the } \\
\text { Estimate }\end{array}$ \\
\hline 1 & $0,741^{\text {a }}$ & 0,550 & 0,505 & 0,12023 \\
\hline
\end{tabular}

Nilai $\mathrm{R}^{2}$ sebesar 0,505 , nilai ini menunjukkan bahwa variabel independen yaitu kepemilikan manajerial, kepemilikan institusional, kepemilikan publik, dewan komisaris dan komite audit dapat menjelaskan variasi variabel dependen yaitu manajemen laba sebesar $50,5 \%$ dan sisanya sebesar $49,5 \%$ dijelaskan oleh variabel lain diluar model regresi ini seperti variabel Ukuran Perusahaan dan Leverage (Dimara \& Hadiprajitno, 2015).

\section{i. Uji Statistik t}

Hasil Uji Statistik t

\begin{tabular}{llllll} 
& \multicolumn{2}{l}{$\begin{array}{l}\text { Unstandardized } \\
\text { Coefficients }\end{array}$} & $\begin{array}{l}\text { Standardized } \\
\text { Coefficients }\end{array}$ & & \\
Model & B & Std. Error & Beta & T & Sig. \\
\hline Konstanta & 0,363 & 0,094 & & 3,869 & 0,000 \\
Kepemilikan Manajerial (X1) & $-0,262$ & 0,56 & $-0,049$ & $-0,465$ & 0,644 \\
Kepemilikan Insitusional (X2) & $-0,497$ & 0,115 & $-0,421$ & $-4,316$ & 0,000 \\
Kepemilikan Publik (X3) & $-0,666$ & 0,121 & $-0,584$ & $-5,480$ & 0,000 \\
Dewan Komisaris (X4) & 0,045 & 0,014 & 0,324 & 3,238 & 0,002 \\
Komite Audit (X5) & 0,005 & 0,013 & 0,035 & 0,346 & 0,731 \\
\hline
\end{tabular}

\section{Pelaporan Hasil Penelitian}

\section{a. Hasil Pengujian Hipotesis Pertama}

Hasil perhitungan uji t menunjukkan bahwa kepemilikan manajerial tidak berpengaruh terhadap manajemen laba. Artinya peningkatan maupun penurunan nilai kepemilikan manajerial tidak mempengaruhi perubahan pada manajemen laba. Berdasarkan hasil analisis statistik deskriptif menunjukkan bahwa nilai rata-rata kepemilikan manajerial yang rendah atau kepemilikan saham oleh pihak manajemen cenderung kecil, yaitu sebesar $0,1 \%$. Sehingga kepemilikan manajerial belum dapat dijadikan sebagai penyatu kepentingan antara pihak manajemen dengan investor karena pihak manajemen yang sekaligus bertindak sebagai investor belum dapat mengendalikan perusahaan sesuai keinginannya sebagai investor (Dimara \& Hadiprajitno, 2017). Oleh karena itu bisa dikatakan bahwa persentase saham yang dimiliki manajemen belum dapat mengurangi adanya manajemen laba. Hal tersebut didukung oleh penelitian Sutino \& Khoiruddin (2016), Rahmawati dkk (2017) dan Dimara \& Hadiprajitno (2017) yang menyatakan bahwa kepemilikan manajerial tidak berpengaruh terhadap manajemen laba. 


\section{b. Hasil Pengujian Hipotesis Kedua}

Hasil perhitungan uji t menunjukkan bahwa kepemilikan institusional berpengaruh negatif terhadap manajemen laba. Artinya apabila persentase kepemilikan saham institusional bertambah, maka akan mengurangi peluang adanya manajemen laba. Dan apabila persentase kepemilikan saham institusional berkurang, maka akan lebih besar peluang adanya manajemen laba. Hasil analisis statistik deskriptif menunjukkan bahwa nilai rata-rata kepemilikan institusi yang besar yaitu sebesar 55,54\%. Dengan nilai kepemilikan yang besar, pemilik saham institusi akan mendorong peningkatan informasi yang lebih optimal dan melakukan pengawasan terhadap pihak manajemen yang dapat mengurangi perilaku oportunistik manajer sehingga pemilik institusi mendapatkan informasi yang setara dengan manajer dan mengurangi adanya manajemen laba (Sari \& Nur 2013). Kepemilikan institusional yang besar memungkinkan adanya pengawasan yang lebih tinggi terhadap manajemen perusahaan sehingga peluang terjadinya manajemen laba akan lebih kecil. Hal ini didukung oleh penelitian Susanto \& Pradipta (2016), Kusumaningtyas \& Farida (2016), dan Astari \& Suryanawa (2017) yang menyatakan bahwa kepemilikan institusional berpengaruh negatif terhadap manajemen laba.

\section{c. Hasil Pengujian Hipotesis Ketiga}

Hasil perhitungan uji $\mathrm{t}$ menunjukkan bahwa kepemilikan publik berpengaruh negatif terhadap manajemen laba. Artinya, apabila persentase kepemilikan saham publik semakin besar maka akan mengurangi peluang dilakukannya manajemen laba. Dan apabila kepemilikan saham publik semakin kecil maka peluang dilakukannya manajemen laba akan semakin besar. Berdasarkan hasil analisis statistik deskriptif, nilai kepemilikan publik memiliki rata-rata yang besar yaitu sebesar 32,8\%. Hasil penelitian ini menunjukkan bahwa semakin tinggi kepemilikan yang dimiliki oleh publik maka akan semakin meningkatkan pengawasan pemilik saham publik terhadap laporan keuangan yang dihasilkan manajemen (Sriyani, dkk 2015). Keberadaan pemilik saham publik menyebabkan manajemen berkewajiban memberikan informasi keuangan secara berkala sebagai bentuk pertanggungjawaban sehingga mengurangi kemungkinan adanya praktek manajemen laba. Hasil penelitian ini didukung oleh penelitian Sukirno dkk (2017) yang menyatakan bahwa kepemilikan publik berpengaruh negatif terhadap manajemen laba.

\section{d. Hasil Pengujian Hipotesis Keempat}

Hasil perhitungan uji $\mathrm{t}$ menunjukkan bahwa dewan komisaris berpengaruh positif terhadap manajemen laba. Artinya apabila jumlah anggota dewan komisaris semakin besar maka manajemen laba akan meningkat. Dan apabila jumlah anggota dewan komisaris semakin kecil maka nilai manajemen laba akan menurun. Hasil analisis statistik deskriptif menunjukkan bahwa dewan komisaris memiiki nilai rata-rata yang besar yaitu 3,6. Hasil penelitian ini menunjukkan bahwa ukuran dewan komisaris memiliki pengaruh positif terhadap manajemen laba. Secara umum dewan komisaris ditugaskan dan diberi tanggung jawab atas pengawasan kualitas informasi yang terkandung dalam laporan keuangan (Nasution dan Setiawan, 2007). Ukuran dewan 
komisaris yang kecil lebih efektif dalam melakukan tindakan pengawasan dibandingkan dewan komisaris yang berukuran besar. Hal ini disebabkan ukuran dewan komisaris yang besar dianggap kurang efektif dalam menjalankan fungsinya sebagai alat monitoring kegiatan manajemen karena sulit dalam komunikasi, koordinasi serta pembuatan keputusan sehingga lebih memungkinkan terjadinya manajemen laba. Hal tersebut didukung oleh penelitian Murtini \& Mansyur (2012), Kristiani (2014) dan Dwiharyadi (2017) yang menyatakan bahwa dewan komisaris berpengaruh positif terhadap manajemen laba.

\section{e. Hasil Pengujian Hipotesis Kelima}

Hasil perhitungan uji $\mathrm{t}$ menunjukkan bahwa komite audit tidak berpengaruh terhadap manajemen laba. Artinya berkurang atau bertambahnya jumlah komite audit tidak memiliki pengaruh terhadap meningkat atau menurunnya manajemen laba. Berdasarkan hasil analisis statistik deskriptif variabel komite audit memiliki nilai rata-rata yang kecil yaitu sebesar 3,8. Hasil penelitian ini menunjukkan bahwa ukuran komite audit tidak berpengaruh terhadap terjadinya manajemen laba, hal ini terjadi karena tujuan perusahaan membentuk komite audit hanya sekedar untuk memenuhi peraturan pemerintah. Hal ini menunjukkan bahwa komite audit telah gagal melakukan tugasnya dalam pengawasan pengelolaan perusahaan serta membantu dewan komisaris terutama yang berhubungan dengan kebijakan akuntansi perusahan, pengawasan internal, dan sistem laporan keuangan (FCGI, 2008). Anggota komite audit tidak secara aktif menjalankan tugasnya sebagai komite audit sehingga fungsi pengawasan tidak berjalan dengan baik. Hasil Penelitian ini didukung oleh penelitian Taco \& Ilat (2017), Muda dkk (2018), dan Giovani (2019) yang menyatakan bahwa komite audit tidak berpengaruh terhadap manajemen laba.

\section{SIMPULAN DAN SARAN}

Berdasarkan hasil pengujian yang telah dilakukan pada perusahaan High Dividend 20 yang terdaftar di BEI tahun 2018-2019, maka dapat diambil kesimpulan sebagai berikut:

1. Kepemilikan Manajerial tidak berpengaruh terhadap manajemen laba.

2. Kepemilikan Institusional berpengaruh negatif terhadap manajemen laba.

3. Kepemilikan Publik berpengaruh negatif terhadap manajemen laba.

4. Dewan Komisaris berpengaruh positif terhadap manajemen laba.

5. Komite Audit tidak berpengaruh terhadap manajemen laba.

Berdasarkan simpulan yang diperoleh serta keterbatasan dalam penelitian, maka saran-saran yang diajukan adalah sebagai berikut:

1. Menambahkan variabel lain yang lebih luas yang dapat mempengaruhi manajemen laba seperti variabel Ukuran Perusahaan, Leverage, dan lain-lain.

2. Peneliti selanjutnya diharapkan meneliti sektor/indeks lain yang memiliki komponen data penelitiannya lebih lengkap dibandingkan dengan indeks High Dividend 20.

3. Menggunakan variabel lain selain Manajemen Laba sebagai variabel dependen. 


\section{DAFTAR PUSTAKA}

Astari, A. A. M. R., \& Suryanawa, I. K. (2017). Faktor-faktor yang mempengaruhi manajemen laba. E-Jurnal Akuntansi Universitas Udayana, 20(1), 290-319

Copeland, R. M. (1968). Income smoothing. Journal of accounting research, 101 116.

Dimara, R. J. S., \& Hadiprajitno, P. B. (2017). Pengaruh Struktur Kepemilikan Manajerial, Ukuran Perusahaan, Kualitas Audit, Komite Audit dan Leverage terhadap Manajemen Laba. Diponegoro Journal of Accounting, 6(4), 462472.

Dwiharyadi, A. (2017). Pengaruh keahlian akuntansi dan keuangan komite audit dan dewan komisaris terhadap manajemen laba. Jurnal Akuntansi Dan Keuangan Indonesia, 14(1), 75-93.

FCGI. 2008. Peranan dewan komisaris dan komite audit dalam pelaksanaan corporate governance (Tata Kelola Perusahaan) Jilid II. Jakarta:Citra graha.

Fischer, M., \& Rosenzweig, K. (1995). Attitudes of students and accounting practitioners concerning the ethical acceptability of earnings management. Journal of business ethics, 14(6), 433-444.

Ghozali, Imam, 2011. Aplikasi Analisis Multivariate dengan program IBM SPSS 19", Edisi 5 Cetakan V, Badan Penerbit Universitas Diponegoro, Semarang.

Ghozali, Imam, 2013 “Aplikai Analisis Multivarite dengan SPSS” Edisi Keempat, Badan Penerbit Universitas Diponegoro, Semarang.

Giovani, M. (2019). Pengaruh Struktur Kepemilikan, Tata Kelola Perusahaan, dan Karakteristik Perusahaan Terhadap Manajemen Laba. Jurnal Akuntansi Bisnis, 15(2), 290-306.

Herawaty, S. A. (2007). Analisis pengaruh independensi, mekanisme corporate governance, dan kualitas audit terhadap integritas laporan keuangan.

Jensen, Michael C. dan W.H. Meckling. 1976. Theory of The Firm: Managerial Behavior, Agency Cost and Ownership Structure. Journal of Financial Economics, Vol. 3, h. 305-360

Kristiani, K. E., Sulindawati, N. L. G. E., Herawati, N. T., \& AK, S. (2014). Pengaruh Mekanisme Corporate Governance Dan Ukuran Perusahaan Terhadap Manajemen Laba Pada Perusahaan Manufaktur Yang Terdaftar Di BEI. JIMAT (Jurnal Ilmiah Mahasiswa Akuntansi) Undiksha, 2(1).

Kusumaningtyas, M., \& Farida, D. N. (2016). The Influence of Audit Committee and Ownership Structure on Earnings Management. Jurnal Dinamika Akuntansi, 8(1), 1-13.

Muda, I., Maulana, W., Sakti Siregar, H., \& Indra, N. (2018). The Analysis of Effects of Good Corporate Governance on Earnings Management in Indonesia with Panel Data Approach. Iranian Economic Review, 22(2), 599625.

Murtini, U., \& Mansyur, R. (2012). Pengaruh Corporate Governance Terhadap Manajemen Laba Perusahaan di Indonesia. Jurnal Riset Akuntansi dan Keuangan, 8(1), 69-78. 
Nasution, M., \& Setiawan, D. (2007). Pengaruh corporate governance terhadap manajemen laba di industri perbankan Indonesia. Simposium Nasional Akuntansi X, 1(1), 1-26.

Pricilia, S., \& Susanto, L. (2017). Pengaruh kepemilikan institusional, kepemilikan manajerial, komisaris independen, dan ukuran dewan komisaris terhadap manajemen laba serta implikasinya terhadap kinerja keuangan pada perusahaan manufaktur yang terdaftar di bursa efek indonesia periode 2012-2014. Jurnal Ekonomi, 22(2).

Salim, M. N., \& Hn, M. R. (2015). Effect of Good Corporate Governance (GCG) Mechanism on Earning Management Practices and the Impact on Stock Returns (Case Study on LIQUID (1Q 45) Companies Listed in Indonesia Stock Exchange Period 2013-2017). Business and Management Studies, 5(3), 11-20.

Saptantinah, Astuti Dewi Puji. 2005. Analisis Faktor-Faktor Yang Mempengaruhi Motivasi Manajemen Laba Di Seputar Right Issue. Universitas Slamet Riyadi. Surakarta.

Sari, S. R. \& Nur, F.A. (2013). Pengaruh leverage dan mekanisme good corporate governance terhadap manajemen laba. Jurnal Ilmu Riset Akuntansi, 2(6).

Sukirno, S., Dewanti, P. W., \& Ningsih, A. P. (2017). Pengaruh Komite Audit, Kepemilikan Institusional, Dan Persentase Saham Publik Terhadap Aktivitas Manajemen Laba.

Susanto, Y. K., \& Pradipta, A. (2016). Corporate governance and real earnings management. International Journal of Business, Economics and Law, 9(1), 17-23.

Sutino, E. R. D., \& Khoiruddin, M. (2016). Pengaruh good corporate governance terhadap manajemen laba pada perusahaan yang masuk dalam JII (Jakarta Islamic Index) tahun 2012-2013. Management Analysis Journal, 5(3).

Taco, C., \& Ilat, V. (2017). Pengaruh Earning Power, Komisaris Independen, Dewan Direksi, Komite Audit dan Ukuran Perusahaan terhadap Manajemen Laba pada Perusahaan Manufaktur yang Terdaftar di Bursa Efek Indonesia. Jurnal EMBA: Jurnal Riset Ekonomi, Manajemen, Bisnis dan Akuntansi, $4(4)$. 